\title{
SIMULASI MODEL PENGEMBANGAN GASIFIKASI LISTRIK BERBASIS BIOMASA HUTAN TANAMAN ENERGI
}

\author{
Mira Yulianti ${ }^{\mathrm{a}, \mathrm{b}^{*}}$, Dodik Ridho Nurrochmat ${ }^{\mathrm{b}}$, Budi Kuncahyo ${ }^{\mathrm{b}}$ \\ ${ }^{a}$ Badan Litbang dan Inovasi Kehutanan dan Lingkungan Hidup, Kementerian Lingkungan Hidup \\ dan Kehutanan Republik Indonesia \\ b Departemen Manajemen Hutan, Fakultas Kehutanan Institut Pertanian Bogor \\ *E-mail: mira_solvay@yahoo.com
}

\section{RINGKASAN}

Kajian ini bertujuan untuk merumuskan strategi kebijakan pengembangan model gasifikasi listrik berbasis biomasa di daerah-daerah pinggiran, melalui pembangunan Hutan Tanaman Energi (HTE). Pengelolaan data dilakukan dengan regresi logit, gap analysis dan dirangkum dalam permodelan sistem dinamis. Hasil analisis menunjukkan bahwa masyarakat sangat bergantung pada listrik dan produknya dan bersedia untuk membayar lebih akibat adanya listrik. Jika hutan tanaman dialokasikan untuk menyediakan biomasa yang akan digunakan untuk listrik maka strategi utama yang harus disiapkan adalah menjamin kepastian harga beli bahan baku biomasa sehingga menjamin kelayakan usaha pemegang ijin hutan tanaman. Pengembangan biomasa terutama kaliandra dipandang penting karena mampu menyediakan energi primer yang berdasarkan kajian ini masih jauh antara rencana dengan realisasi. Rasio elektrifikasi akan lebih cepat tercapai jika hutan tanaman energi dengan jenis kaliandra dikembangkan dengan serius. Untuk itu, strategi yang sesuai adalah menjamin harga bahan baku di angka Rp 400.000/ton dan pengaturan intensitas panen. Strategi pemungkin lain adalah subsidi untuk instalasi pembangkit listrik gasifikasi.

Kata Kunci: analisis gap, energi biomasa, gasifikasi listrik, hutan tanaman energi, model sistem dinamis

\section{PERNYATAAN KUNCI}

- Akar masalah yang mempengaruhi listrik belum teraliri adalah kapasitas sistem kelistrikan yang terbatas, return of investment (ROI) yang rendah dan ketergantungan pada bahan bakar minyak fosil (BBM) sebagai pembangkit listrik.
- Kebijakan satu harga BBM di seluruh wilayah Indonesia menyebabkan membengkaknya subsidi karena besarnya biaya transportasi dan distribusi dari kilang minyak ke seluruh tanah air.

- Ketersediaan BBM di setiap daerah sangat beragam sehingga pemanfaatan sumber energi baru dan terbarukan 
sesuai dengan karakteristik lokal sangat diperlukan, untuk menjamin keberlanjutan dan efisiensi penggunaan sumber energi di seluruh pelosok negeri.

- Biomasa adalah salah satu sumber energi baru dan terbarukan yang sangat potensial untuk dikembangkan di masa depan karena tersedia melimpah hampir di semua daerah di Indonesia.

\section{REKOMENDASI KEBIJAKAN}

- Pengembangan energi baru dan terbarukan sangat penting dilakukan untuk mengurangi ketergantungan pada bahan bakar minyak fosil (BBM).

- Perlu dipertimbangkan pengalihan subsidi BBM untuk pengembangan energi baru dan terbarukan, terutama di daerah-daerah pelosok, terdepan, dan terluar yang sulit dijangkau distribusi BBM dalam rangka peningkatan efisiensi dan kemandirian energi berbasis karakteristik lokal.

- Gasifikasi listrik berbasis biomasa adalah salah satu pemanfaatan energi baru dan terbarukan yang potensial dikembangkan di Indonesia, dengan dukungan bahan baku yang kontinu dari Hutan Tanaman Energi.

- Kaliandra adalah salah satu jenis pohon yang sesuai untuk dikembangkan dalam skema Hutan Tanaman Energi di Indonesia.

\section{PENDAHULUAN}

Pemenuhan kebutuhan BBM dan listrik di daerah-daerah pelosok, terdepan, dan terluar memerlukan biaya transportasi, distribusi, dan operasional lainnya yang sangat besar (Nizam 2008). Pemerintah harus semakin banyak mengalokasikan anggaran untuk subsidi, untuk menjamin ketersediaan dan harga BBM serta listrik yang seragam dan terjangkau di semua wilayah Indonesia. Dalam hal pemenuhan energy, Indonesia saat ini menghadapi permasalahan dalam tiga kelompok besar, yaitu: tingkat elektrifikasi yang masih rendah, ketergantungan pada sumber energi fosil, dan rendahnya pemanfaatan Energi Baru Terbarukan (EBT). Oleh karena itu, diperlukan strategi yang tepat untuk memenuhi kebutuhan energi dimasa mendatang. Salah satu kebijakan yang perlu dilakukan adalah melalui integrasi dan diversifikasi energi, dengan perubahan komposisi penggunaan secara bertahap yang mengarah pada jenis energi baru dan terbarukan yang semakin besar (Triatmojo 2013).

Diversifikasi energi dapat dilakukan dengan mengembangkan beragam sumber energi untuk penyediaan konsumsi energi domestik yang efisien sesuai dengan potensi dan karakteristik lokal. Indonesia memiliki beragam sumber energi, tidak hanya yang bersumber dari minyak dan gas bumi atau 
batubara yang saat ini sudah banyak kontinuitas suplai bahan baku dan digunakan, tetapi juga panas bumi kesesuaian jenis bahan baku. Biomasa di (geothermal), gambut, energi air, biogas, sektor kehutanan umumnya berbasis kayu biomasa, matahari, angin, gelombang laut (Bildirici \& Özaksoy 2016) dan dapat dan sumber energi lainnya. Menurut Kholik dikembangkan melalui IUPHHK-HT (Izin (2015), potensi sumber daya energi tersebar di seluruh wilayah Indonesia sesuai dengan karakteristik dan kondisi geologinya. Pemanfaatan sumber energi baru dan terbarukan berbasis potensi lokal akan menjamin keberlanjutan dan efisiensi penggunaannya, serta sesuai dengan budaya masyarakat setempat (Juwito et al 2012).

Biomasa di Indonesia yang berpotensi untuk dikembangkan sebagai sumber energi sebesar 32.654 MW, sementara saat ini baru dikembangkan sebesar 1.716,5 MW atau kurang dari 4\%, sehingga perlu kebijakan penggunaan energi baru dan terbarukan, khususnya biomasa sehingga dapat meningkatkan rasio elektrifikasi (Direktorat Jenderal Anggaran 2016). Karena ini kendala terbesar, maka sejatinya tulisan ini memeberikan rekomendasi bagaimana mengatasi permaslahan ini. Menurut IRENA (2015) harga listrik final dari gasifikasi biomasa mencapai 0,25 USD/kWh, jauh lebih tinggi dibandingkan harga listrik dari bahan bakar fosil yang hanya sekitar $0,15 \mathrm{USD} / \mathrm{kWh}$.

Salah satu penentu efisiensi dalam pengembangan EBT biomasa adalah Usaha Pemanfaatan Hasil Hutan Kayu Hutan Tanaman) sebagaimana diatur dengan Peraturan Menteri Lingkungan Hidup dan Kehutanan No. P.12/MenLHK-II/2015 tentang Pedoman Pembangunan Hutan Tanaman Industri (HTI). Peraturan ini juga mengatur alokasi lahan sebesar 20\% untuk tanaman kehidupan yang bertujuan untuk mengakomodir pertumbuhan ekonomi lokal dan untuk kebutuhan keseharian masyarakat di sekitar hutan, diantaranya untuk memenuhi kebutuhan energy -atau yang lebih dikenal dengan istilah Hutan Tanaman Energi (HTE).

Banyaknya permasalahan antara interaksi ekosistem hutan dan sistem sosial yang tidak lengkap dan belum ada sinergitas sehingga diperlukan analisis system,dalam keadaan demikian analisis sistem dan simulasi sering dipakai untuk menguji hipotesis tentang bagaimana sistem bekerja (Grant et al 1997). Jika ingin memodelkan sistem hutan maka skenario untuk mengelola hutan secara lestari dapat dihipotesiskan, penggunaan pemodelan sistem sebagai alat bantu untuk memahami kondisi sesungguhnya. Pemodelan sistem berangkat dari keinginan untuk memahami dunia nyata 
dengan mentransformasi ke sebuah model menggunakan berbagai metode (Purnomo 2004). Telah banyak teknik pemodelan yang digunakan untuk memecahkan masalah pengelolaan hutan, seperti penggunaan pendekatan kuantitatif. Namun, karena dunia nyata memiliki situasi masalah yang sangat kompleks dan tidak terstruktur maka tidak semua realitas yang ada dapat dipahami. Perangkat lunak dinamika sistem seperti Stella, Powersim, Simile dan Vensim membantu memformulasikan model dari komponen-komponen stok (stock) dan aliran (flow) (Purnomo 2003)

Penelitian ini dirancang untuk mensintesa strategi dalam mewujudkan terlaksananya killer variable dengan diupayakannya pembangunan unit dari hulu dengan kebijakan yang tumbuh dan berjalan dengan baik, sehingga untuk model yang didaerah tidak terjangkau dan remote area dapat memanfaatkan biomassa dari HTI. Dengan pertimbangan aspek kebijakan, pembangunan HTE baik jenis tanaman yang digunakan, pertumbuhan dan pengaturan hasil juga aspek ekonomi dan sosial yang mungkin muncul dengan HTE

\section{SITUASI TERKINI}

Kebutuhan energi nasional meningkat, sementara produksi energi terus menurun yang berakibat pada tingkat ketergantungan negara pada sumber energi impor serta keinginan pemerintah saat ini yang ingin menggalakkan pemanfaatan sumber energi alternatif menjadikan energi biomasa dari hutan harus segera dijalankan (Kholiq 2015). Salah satu jenis teknologi yang dapat dikembangkan untuk penyediaan energi listrik berbasis biomasa adalah gasifikasi. Teknologi ini sangat berpotensi menggantikan pembangkit listrik berbasis BBM, terutama di daerah-daerah yang jauh dari lokasi pembangkit listrik konvensional. Gasifikasi listrik berbasis biomas juga dapat dibuat dalam skala kecil, sehingga dianggap sesuai untuk negara berkembang (Stassen 1995). Jenis tanaman merupakan salah satu variabel yang sangat menentukan keberlanjutan pasok bahan baku dan kelayakan usaha EBT biomasa. Kaliandra (Calliandra callotbyrsus) merupakan jenis pohon yang dapat menghasilkan biomasa dengan nilai kalor yang tinggi berkisar antara 3.100-3.600 kkal/kg (Abdulah et al. 2015), bersifat coppice, mudah untuk dibudidayakan baik untuk tujuan konservasi, mendukung ketahanan pangan serta untuk alasan memperbaiki kondisi tanah yang marginal (Chamberline 2000). Sebaran Kaliandra sangat sempit karena hanya akan tumbuh baik di ketinggian tempat antara 400 m.dpl600 m.dpl (Hendarti dan Hidayati 2014).

Selama ini pemanfaatan kaliandra sebagai salah satu komoditas yang dapat dikembangkan dalam skala luas dan skala 
industri untuk menyiapkan bahan baku energi biomasa belum dilakukan. Perlu kajian mendalam terkait teknik silvikultur, pertumbuhan dan hasil, kajian nilai keekonomian dan keterterimaan sosial terhadap konsep HTE. Untuk itu, yang menjadi pertanyaan dalam penelitian ini adalah:

1. Gap analysis terhadap target dan capaian usaha pemerintah dalam memenuhi target energi listrik khususnya dengan tanpa HTE? Apakah HTE akan membantu pencapaian?

2. Jika HTE dikatakan ya pada pertanyaan (1), apa rangsangannya (aspek ekonomi) kepastian bahwa ada demand dan faktor apa yang mempengaruhi?

3. Peluang apa yang dapat dimanfaatkan untuk merangsang pemegang ijin HTI untuk mengembangkan HTE? Persepsi ketergantungan masyarakat terhadap listrik? Subsidi pemerintah terhadap pengembangan EBT

4. Bilamana ada ketertarikan untuk membangun HTE, bagaimana simulasi variabel yang kompleks dalam menjelaskan kemungkinankemungkinan yang akan muncul terutama aspek finansial bagi pemegang ijin HTE?

\section{METODOLOGI}

Upaya penyediaan dalam bentuk pembangunan IUPHHK-HT harus memberikan dampak positif bagi pemegang IUPHHK-HT, berdampak pada pemulihan produktivitas hutan dan ekologi serta layak secara sosial melalui pendekatan analisis sistem dinamis (Gambar 1).

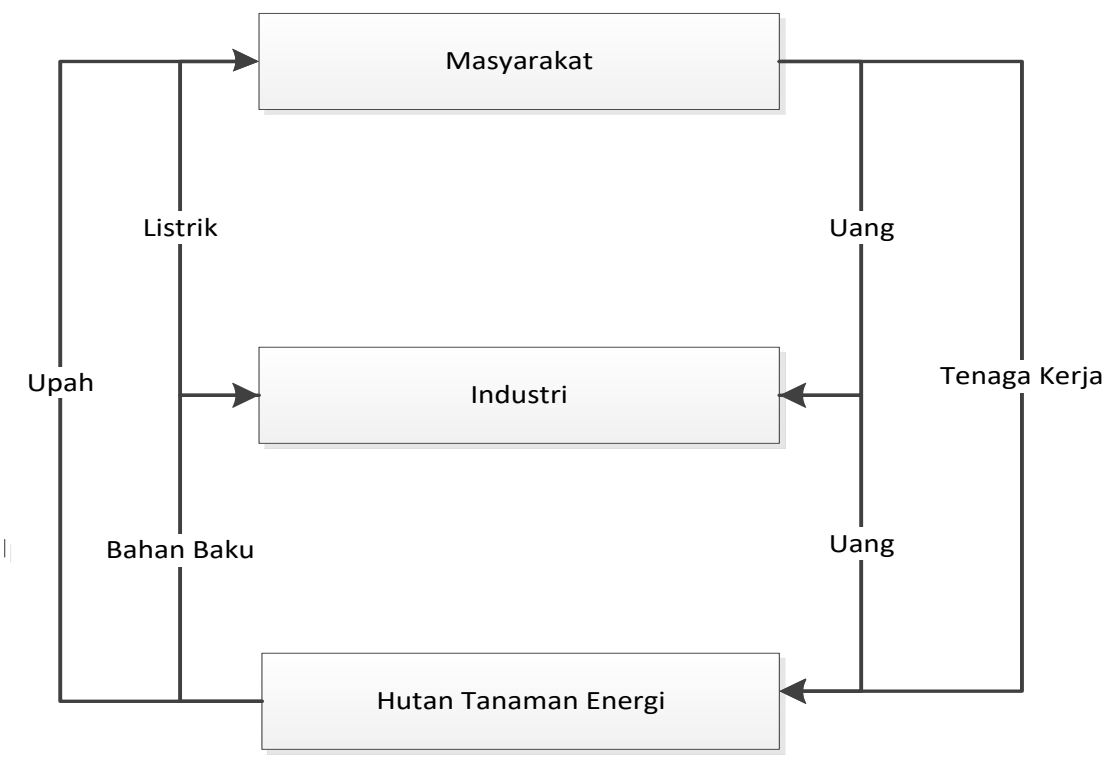

Gambar 1. Kerangka Pemikiran 


\section{TEMPAT DAN WAKTU PENELITIAN}

Pemilihan lokasi mempertimbangkan penelitian pemanfaatan peruntukan lahan Jenis Kaliandra dengan lokasi Petak Ukur Permanen (PUP) yang telah ada di Kuningan dan Majalengka. Penelitian ini dilaksanakan pada bulan Juli 2016 hingga Oktober 2016.

\section{ALAT DAN BAHAN}

Alat yang digunakan dalam penelitian ini adalah GPS receiver, kompas, caliper, meteran rol, tali nilon, timbangan, golok, gergaji

Tabel 1. Jenis dan Sumber Data

\begin{tabular}{|c|c|c|c|c|c|}
\hline No & Komponen & Aspek & Jenis Data & $\begin{array}{c}\text { Metode } \\
\text { Pengumpulan } \\
\text { Data }\end{array}$ & $\begin{array}{c}\text { Metode Analisis } \\
\text { Data }\end{array}$ \\
\hline 1 & Kebijakan & $\begin{array}{l}\text { - Dasar dibuat kebijakan } \\
\text { - Tujuan dan sasaran } \\
\text { - Strategi pencapaian tujuan } \\
\text { - Instansi pelaksana } \\
\text { - Tata waktu pelaksana }\end{array}$ & $\begin{array}{l}\text { Data } \\
\text { sekunder }\end{array}$ & $\begin{array}{l}\text { Pengumpulan } \\
\text { literatur }\end{array}$ & $\begin{array}{l}\text { Studi literature } \\
\text { (Analisis GAP) }\end{array}$ \\
\hline 2 & $\begin{array}{l}\text { Pertumbuhan } \\
\text { dan Hasil }\end{array}$ & $\begin{array}{l}\text { - Pertumbuhan trubusan } \\
\text { setelah pangkasan } \\
\text { - Biomasa Panen } \\
\text { - Nilai Kalor Hasil } \\
\text { Pangkasan }\end{array}$ & $\begin{array}{l}\text { Data } \\
\text { sekunder }\end{array}$ & $\begin{array}{l}\text { Pengecekan } \\
\text { PUP, } \\
\text { Wawancara dan } \\
\text { pengumpulan } \\
\text { data sekunder }\end{array}$ & 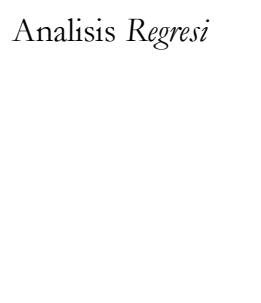 \\
\hline 3 & $\begin{array}{l}\text { Survey pengguna } \\
\text { listrik }\end{array}$ & $\begin{array}{l}\text { - Jumlah Pendapatan } \\
\text { Rumah Tangga } \\
\text { - Jumlah Konsumsi } \\
\text { - Peralatan elektronik yang } \\
\text { digunakan } \\
\text { - Alokasi dana untuk } \\
\text { belanja listrik }\end{array}$ & $\begin{array}{l}\text { Data } \\
\text { primer }\end{array}$ & $\begin{array}{l}\text { Wawancara } \\
\text { tersistematik } \\
\text { (Tertutup) }\end{array}$ & Analisis logit \\
\hline
\end{tabular}




\section{JENIS DAN SUMBER DATA}

Jenis Pengumpulan data penelitian yang digunakan dalam penelitian terdiri atas data primer dan data sekunder, dengan cara: (1) Observasi atau pengamatan langsung di lapangan, (2) Wawancara; melakukan komunikasi langsung kepada responden dengan menggunakan tehnik kuisioner, (3) Pencatatan; mencatat semua data sekunder dari berbagai instansi yang berkaitan dengan penelitian, (4) Studi literatur, yaitu pengumpulan data dari berbagai sumber, diantaranya: jurnal, buku, hasil penelitian, prosiding, atau tulisan ilmiah lainnya. Data primer diperoleh melalui wawancara dan menggunakan kuisioner terhadap 60 responden dengan cara purposive sampling. Sementara data sekunder diperoleh dari berbagai sumber antara lain data laporan, statistik dan kebijakan HTI serta Ketahanan Energi Nasional (KEN) dan data pertumbuhan dan hasil serta teknik silvikultur kaliandra .

\section{ANALISIS DATA}

1. Analisis Kebijakan Pembangunan HTI Analisis dilakukan dengan cara menganalisis isi dari kebijakan yang mengurai tentang apa dan bagaimana HTI tersebut dibangun, membayar kewajiban kepada negara, penyelesaian masalah lingkungan dan pengendalian sosial;

2. Analisis Kebijakan KEN
Harga bahan baku energi biomasa dan bagaimana bahan baku dibayarkan

3. Analisis LOGIT untuk menentukan faktor yang mempengaruhi daya serap masyarakat terhadap energi listrik.

Regresi logistik atau yang disebut Logit merupakan bagian dari analisis regresi. Metode ini menganalisis hubungan pengaruh peubah-peubah penjelas (X) terhadap peubah respon $(\mathrm{Y})$ melalui model persamaan matematis tertentu (Firdaus et al 2011). Model logit adalah model regresi non linear yang menghasilkan sebuah persamaan dimana variabel dependent bersifat kategorikal. Kategori paling dasar dari model tersebut menghasilkan binary values seperti angka 0 dan 1. Angka yang dihasilkan mewakili suatu kategori tertentu yang dihasilkan dari perhitungan probabilitas terjadinya kategori tersebut. Dalam penggunaan model logit seringkali digunakan dalam data klasifikasi, dalam penelitian ini kategori yang digunakan adalah pengguna listrik rumah tangga, dimana nilai 0 memiliki peluang dari menggunakan listrik subsidi dan nilai 1 peluang untuk tidak menggunakan listrik subsidi (non subsidi).

\section{ANALISIS DAN \\ ALTERNATIF SOLUSI}

Ketahanan Energi adalah suatu kondisi terjaminnya ketersediaan energi dan akses masyarakat terhadap energi pada harga yang terjangkau dalam jangka panjang dengan 
tetap memperhatikan perlindungan terhadap lingkungan hidup. Menurut PP. No. 79 Tahun 2014 tentang ketahanan energi nasional (KEN), ketahanan energi didefinisikan sebagai suatu keadaan dimana ketersediaan sumber energi yang tidak terputus dengan harga yang terjangkau. Kebijakan ini dikeluarkan untuk menjamin kecukupan konsumsi energi per kapita secara berkelanjutan karena kondisi energi di Indonesia saat ini belum memiliki cadangan penyangga energi yang dapat memberikan jaminan pasokan dalam waktu tertentu apabila terjadi kondisi krisis dan darurat energi (BIN 2014). KEN disusun sebagai pedoman untuk memberi arah pengelolaan energi nasional guna mewujudkan kemandirian energi dan ketahanan energi nasional untuk mendukung pembangunan nasional berkelanjutan.

Tuntutan penyediaan listrik dari berbagai sumber terutama dari EBT semakin tinggi. Penggunaan peralatan energi untuk mendukung kelangsungan hidup masyarakat diproyeksikan mencapai 59\% dengan asumsi rasio elektrifikasi mencapai $100 \%$ di tahun 2030 yang mengakibatkan kebutuhan listrik meningkat mencapai 142 juta SBM (235 TWh) di tahun 2050 (BPPT 2016). Pembangunan EBT untuk memenuhi laju permintaan listrik sampai dengan tahun 2015 masih di angka $0,15 \%$ atau hanya mencapai 58,25 MW. Sumber bahan baku EBT yang telah digunakan adalah surya, angin, air baik itu mini dan micro hidro serta panas bumi. Pembangunan Hutan Tanaman Industri diawali karena kekurangannya stock bahan baku sedangkan potensi permintaan didunia sangat tinggi dan hutan tanaman menyumbang sekitar sepertiga produksi kayu bulat industri dunia pada 2012 Jurgensen et al 2014). Tren pertumbuhan jumlah pemegang ijin HTI cenderung turun dari tahun ke tahun. Di tahun 2001, jumah pemegang ijin mencapai 404 perusahaan, sementara tersisa 277 perusahaan di tahun 2014, dengan jumlah HTI terbanyak (59 perusahaan) di daerah Kalimantan Timur ( KLHK 2015). Penurunan jumlah unit berkorelasi positif dengan produksi kayu bulat HTI. Jumlah produksi kayu bulat HTI di tahun 2001 mencapai $8.158 .403 \mathrm{~m}^{3}$ yang didominasi jenis kayu meranti mencapai $3.742 .865 \mathrm{~m}^{3}$. Sementara produksi kayu bulat HTI di tahun 2014 hanya mencapai $5.447 .041 \mathrm{~m}^{3}$. Dengan kata lain terjadi penurunan produksi 33\% selama tahun 2001 - 2014 atau 2,5\% per tahun. Penurunan ini diakibatkan oleh sejumlah faktor. Sudarmalik (2014) menjelaskan bahwa terdapat beberapa permasalahan pembangunan hutan tanaman yang menjadi faktor kendala perbaikan produktivitas hutan seperti (1) usaha pembangunan HTI diwujudkan dalam monopoli areal dan kepemilikan usaha serta monopsoni pasar kayu; (2) timbulnya 
penguasaan areal dan usaha pembangunan HTI menyebabkan biaya transaksi tinggi dalam proses permohonan ijin Usaha PHHK-HT dan proses pembangunan HTI;

(3) konflik tenurial antara masyarakat setempat dengan pemegang ijin. Untuk memperbaiki hubungan produksi dengan masalah tenurial maka perlu dikembangkan HTI sebagai sebuah wadah interaksi kebutuhan masyarakat lokal dengan kebutuhan nasional. Salah satu jenis yang dapat dikembangkan adalah energi biomasa. Energi biomasa dapat menyediakan listrik bagi daerah yang tidak terakses atau daerah dengan harga energi yang mahal. Selain itu energi biomasa mampu menyediakan kesempatan kerja bagi masyarakat setempat, menurunkan ketergantungan nasional terhadap skema perdagangan minyak dunia serta meningkatkan simpanan devisa. Dampak ekologi yang dapat diperoleh adalah meningkatkan serapan $\mathrm{CO}_{2}$ serta konservasi tanah dan air.

Potensi pengembangan energi biomasa di HTI sangat besar. Peluang untuk memperoleh bahan baku secara kontinyu juga sangat terbuka dibandingkan potensi dari residu (sisa panen produk pertanian, logging waste atau sampah perkotaan), atau produk alternatif (bahan bakar nabati vs produk turunan sawit atau perkebunan jenis tertentu). Hutan tanaman yang diperuntukkan untuk pembangkit listrik energi terbarukan yang dapat menyediakan suplai bahan baku berkelanjutan dan kontinyu yang relatif bebas dari kondisi cuaca dibanding sumber energi lain seperti energi matahari atau air (BAPPENAS dan CIFOR 2016).atau dapat juga dikelola dalam model lanskap Agroforestri (arifin et al 2009)

Strategi ini selaras dengan kebijakan Pemerintah melalui Peraturan Menteri Kehutanan P.55/Menhut-II/2011 tentang Usaha pemanfaatan hasil hutan kayu pada hutan tanaman dan P.39/Menhut-II/2013, yakni masyarakat di dalam kawasan hutan diberi hak untuk mengelola lahan maksimal 2 ha per kepala keluarga $(\mathrm{KK})$ di areal kehidupan dengan menggunakan Tanaman Kehutanan. Selain itu dengan Peraturan Menteri Lingkungan Hidup dan Kehutanan No. P.12/MenLHK-II/2015 tentang Pedoman Pembangunan HTI telah mengalokasikan paling sedikit 20\% lahan untuk tanaman kehidupan yang bertujuan untuk mengakomodir pertumbuhan ekonomi lokal dan untuk kebutuhan keseharian masyarakat di sekitar hutan. Bila alokasi lahan tersebut dioptimalkan untuk produksi bahan baku biomasa maka kelimpahan dan akses bahan baku akan sangat tinggi sehingga dapat memudahkan produksi listrik biomasa dan akan berakibat pada biaya produksi yang rendah serta menjamin keberlanjutan suplai bahan baku (sustainable raw materials supply). 
Untuk meningkatkan ketahanan energi nasional, maka salah satu sektor yang dapat dimanfaatkan adalah kehutanan melalui pembangunan hutan tanaman energi (HTE). Dengan luas hutan produksi mencapai 60 juta ha, maka potensi konversi biomasa hutan menjadi listrik mencapai 32.654 MW dari limbah pemanfaatan hasil hutan tanaman. (Direktorat Jenderal Anggaran 2016). Model dinamika sistem yang dibuat memiliki batasan model yang dibangun tidak mempertimbangkan teknik silvikultur optimal dan nilai jual merupakan stumpage value (harga bahan baku dihutan) sehingga tidak mempertimbangkan biaya transportasi dan biaya lainnya terkait pemindahan material.

Produktivitas lahan sebagai penyedia bahan baku gasifikasi listrik sangat bergantung pada variabel kerapatan tegakan dan luas lahan pengusahaan. Alokasi lahan yang besar dan didukung oleh persentase tumbuh tanaman di lapangan yang tinggi akan memproduksi bahan baku biomasa yang tinggi dan menjamin kelestarian pasokan bahan baku untuk listrik biomasa. Namun demikan, terdapat konsekuensi atas tujuan tersebut berupa biaya investasi, teknik silvikultur dan manajemen pembangunan hutan tanaman yang intensif. Teknik silvikultur yang diadopsi akan mempengaruhi persen tumbuh. Sementara biaya investasi dan manajemen pembangunan hutan tanaman akan mempengaruhi sektor kelayakan finansial penyedia bahan baku baik yang sifatnya offgrid maupun on-grid. Berdasarkan pertimbangan tersebut, pendekatan sistem dianggap paling tepat menggambarkan dan memproyeksikan kondisi hutan tanaman untuk tujuan ganda terutama pada penyediaan bahan baku biomasa untuk

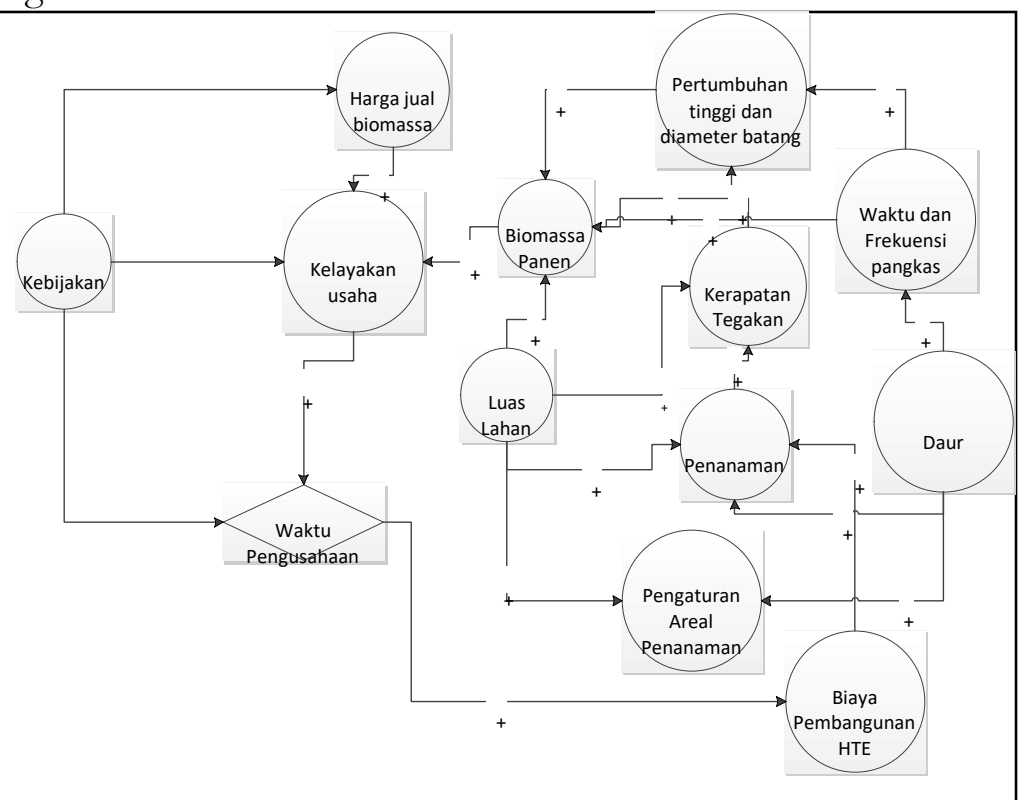

Gambar 2 Model konseptual dinamika sistem yang dikembangka 
pembangkit listrik di daerah yang tidak terakses listrik oleh PLN (Gambar 2).

Penyusun berbagai sub-model terdiri dari variabel-variabel yang saling berinteraksi. Terdapat dua jenis hubungan antar variabel, yaitu hubungan positif $(+)$ dan negatif (-). variabel kerapatan tegakan berkorelasi positif terhadap biaya tanam, produksi kayu, jarak tanam dan luas lahan, sehingga semakin besar luas lahan maka akan semakin besar biaya yang dikeluarkan dan akan semakin besar produksi kayu yang dihasilkan. Model konseptual di atas menggambarkan komponen-komponen yang berpengaruh dalam model pengelolaan hutan tanaman energi. Model dinamika sistem selengkapnya dijelaskan pada spesifikasi model.

\section{SPESIFIKASI MODEL}

Sub Model Rumpun Kaliandra

Pada submodel kaliandra, luas hutan tanaman sebesar 15.000 ha dengan menggunakan sebagian area kerja HTI. Total luas HTI adalah 75.000 ha. Dengan demikian luas areal penanaman tanaman kaliandra sebagai penyedia biomasa untuk listrik adalah sebesar $20 \%$ dari total luas areal kerja efektif sebagaimana diatur dengan Peraturan Menteri Lingkungan Hidup dan Kehutanan No. P.55/Menhut-II/2015 yakni dari 100\% luas ijin HTI, dialokasikan $20 \%$ untuk tanaman kehidupan, 10\% untuk konservasi dan $70 \%$ untuk lahan efektif. Dengan demikian, model ini mencoba membangun hutan tanaman energi di blok untuk tanaman kehidupan. Alasannya adalah memudahkan akses pengurusan dan pengawasan, melibatkan masyarakat serta menekan laju konversi hutan tanaman menjadi perkebunan sebagaimana sedang berkembang saat ini bahwa masyarakat cenderung lebih suka mengembangkan tanaman kelapa sawit atau karet di lokasi dengan peruntukkan tanaman kehidupan.

Dalam sub model ini, areal penanaman di bagi atas 3 blok. Maksud dari pembagian areal kerja ini adalah penanaman disesuaikan dengan umur panen kaliandra. Kaliandra dapat dipanen pada umur 3 tahun setelah tanam, dengan sistem pangkas. Luas setiap blok dibagi sama luas. Produktivitas biomasa panen ditentukan oleh variabel tinggi dan persen hidup. Untuk itu, akan digunakan model penduga tinggi batang dan persentasi hidup sebagaimana dijelaskan pada pembahasan sebelumnya. Jumlah rumpun dapat disebut sebagai kerapatan tegakan yang ditentukan oleh jarak tanam. Penanaman dipengaruhi daur dan usia rumpun. Daur yang digunakan adalah 3 tahun, sehingga jumlah blok tanam terdiri atas 3 blok yang berarti bahwa penanaman dilakukan selam 3 tahun. Setelah itu, dilakukan pemanenan setiap tahun sampai dengan usia pengusahaan 20 tahun dan 
setelah itu dilakukan penanaman kembali. Dalam satu rumpun kaliandra terdapat lebih dari 1 batang. Abdulah et al. (2015) dalam 1 rumpun kaliandra tua terdapat 15-40 batang per rumpun. Setiap pangkasan akan mengakibatkan pertambahan trubusan yang cenderung lebih banyak dari batang awal. Biomasa merupakan fungsi dari volume, sementara volume merupakan fungsi dari pertumbuhan diameter dan tinggi batang hasi pangkasan. Fungsi volume batang terhadap biomasa batang adalah linier.

Sub model Biaya Pembangunan HTI

Berdasarkan PP No.64/MenhutII/2009 tentang standard biaya pembangunan hutan tanaman industri dan hutan tanaman rakyat maka pembangunan hutan energi juga menggunakan dasar dari biaya HTI. Dari mulai awal pembuatan HTI sampai pajak yang digunakan umtuk terlaksananya pembangunan HTI (Gambar 4). Biaya HTI dibagi atas biaya perencanaan, biaya operasional dan administrasi. Biaya perencanaan meliputi biaya perijinan dan penataan areal kerja. Biaya operasional meliputi biaya pembangunan tanaman, pemeliharaan dan pemanenan. Biaya administrasi terkait biaya manajemen. Biaya manajemen meliputi iuran hasil hutan, Provisi Sumber Daya Hutan (PSDH) dan biaya administrasi umum. Bentuk fungsi biaya dalam model ini adalah linier.

Sub Model Pendapatan HTE

Pendapatan merupakan fungsi dari biomasa hasil pangkasan dikalikan harga jual. Sementara pendapatan bersih (netincome) merupakan selisih antara total pendapatan terhadap total biaya.

Sub Model Analisa Kelayakan Usaha

Menurut Gray et al (1985) bahwa kelayakan finansial dan ekonomi suatu kegiatan ditunjukkan oleh nilai NPV (Net Present Value), B/C ratio (Benefit Cost Ratio) atau IRR (Internal Rate of Return). Nilai NPV, $\mathrm{B} / \mathrm{C}$ ratio dan IRR sesungguhnya saling berhubungan. Suatu kegiatan dikatakan layak

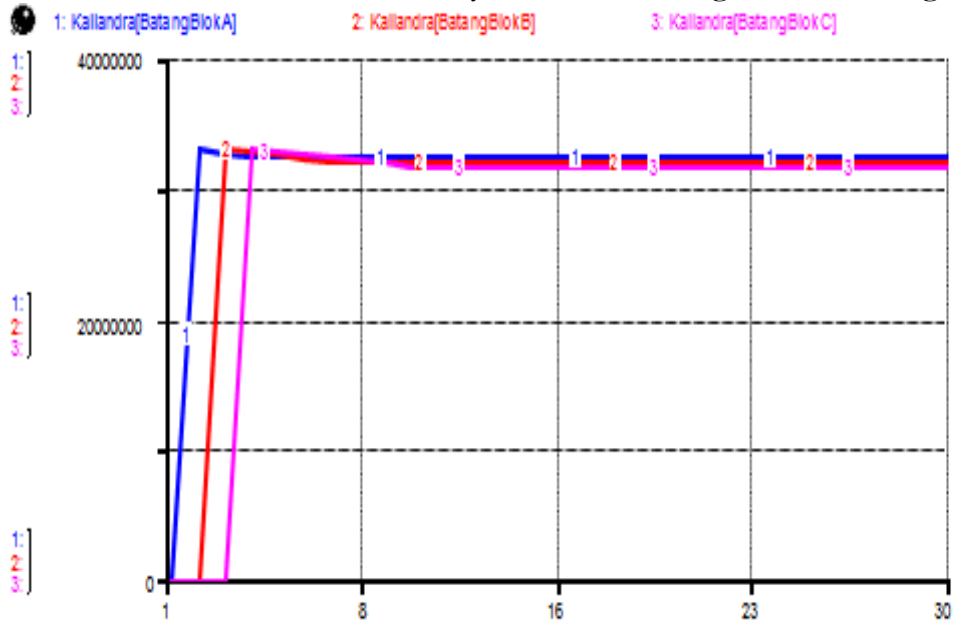

Gambar 3. Jumlah rumpun kaliandra yang ditanam 
secara finansial (menguntungkan bagi perusahaan) bila nilai NPV positif dan atau $\mathrm{B} / \mathrm{C}$ ratio lebih besar dari satu dan atau IRR lebih besar dari tingkat suku bunga diskonto (discount rate). NPV merupakan indikator terpenting karena memperhitungkan nilai waktu dari uang sehingga layak untuk diusahakan (Sadapotto et al 2010). NPV merupakan selisih nilai pendapatan sekarang dengan total biaya dengan melihat tingkat suku bunga. Jika NPV menghasilkan nilai positif maka investasi tersebut dapat diterima, sedangkan jika NPV tersebut bernilai negatif maka sebaiknya investasi tersebut ditolak (Djatmiko 2012). sehingga dalam 3 tahun telah ditanam seluas 15.000 ha yang merupakan $20 \%$ dari luas efektif HTI (Gambar 3).

Jumlah rumpun kaliandra tidaklah statis. Terdapat dinamika pertumbuhan berupa kematian dan pertambahan jumlah batang dalam rumpun. Kematian dapat disebabkan oleh kematian alami dan kematian akibat intensitas pemanenan. Kematian alami disebabkan oleh umur rumpun muda belum mampu beradaptasi kondisi lingkungan (Gambar 4).Gambar 4 menunjukkan bahwa kematian alami akan berbeda menurut blok penanaman. Hal ini karena waktu penanaman setiap blok berbeda sehingga

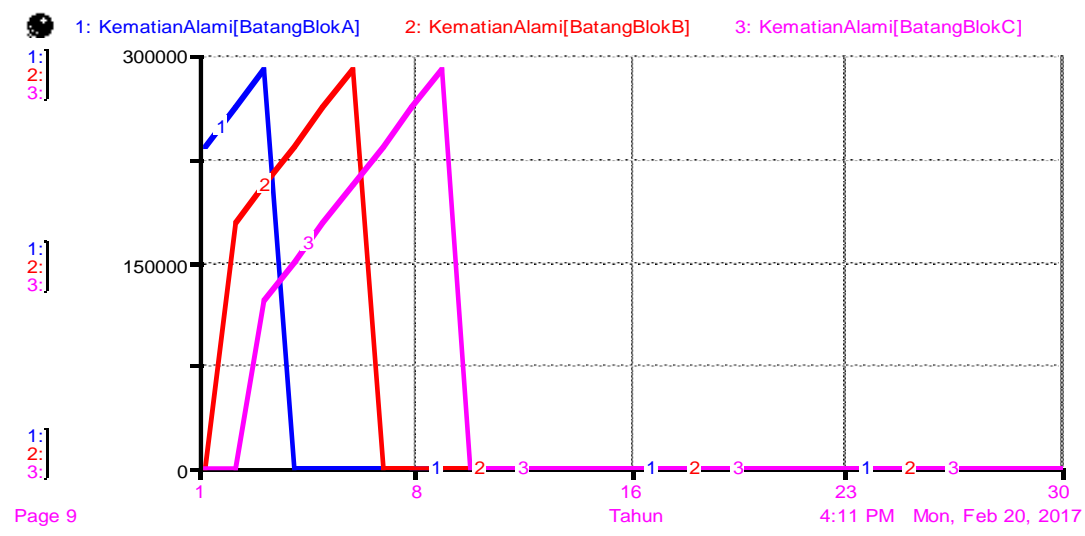

Gambar 4. Tren kematian alami tanaman kaliandra

\section{FORMULASI MODEL}

Perumusan model menunjukkan bagaimana model didasarkan pada rumus matematika dan pendekatan kuantitatif lainnya. Pertumbuhan tegakan kaliandra dimulai dari tahun pertama dengan jumlah rumpun mencapai 6.667 batang/ha atau dengan jarak tanam $1 \times 1,5 \mathrm{~m}$. Luas areal efektif penanaman adalah $5.000 \mathrm{ha} /$ tahun umur tanaman akan berbeda dan pengaruh kematian alami akan berbeda. Namun, jumlah rumpun yang mati cenderung sama. Fenomena ini merupakan salah satu batasan model karena model ini tidak melihat pengaruh perbedaan lingkungan terhadap dinamika kematian rumpun di lapangan. Rumpun tersisa akan tumbuh dan dipanen pada ketinggian pangkas $70 \mathrm{~cm}$ di atas 
permukaan tanah (Abdulah et al. 2015). dengan nilai kalor yang dimiliki batang Obyek yang dipanen adalah batang di dalam kaliandra tua yakni berada pada angka 3600 rumpun, dan kemudian akan tumbuh lebih $\mathrm{kkal} / \mathrm{kg}$. Satu stapel meter kaliandra sama banyak dibandingkan batang sebelum panen dengan $0,7 \mathrm{~m}^{3}$ (Pamoengkas dan Asycarya (Gambar 5). 2015) dan 1 ton kaliandra sama dengan

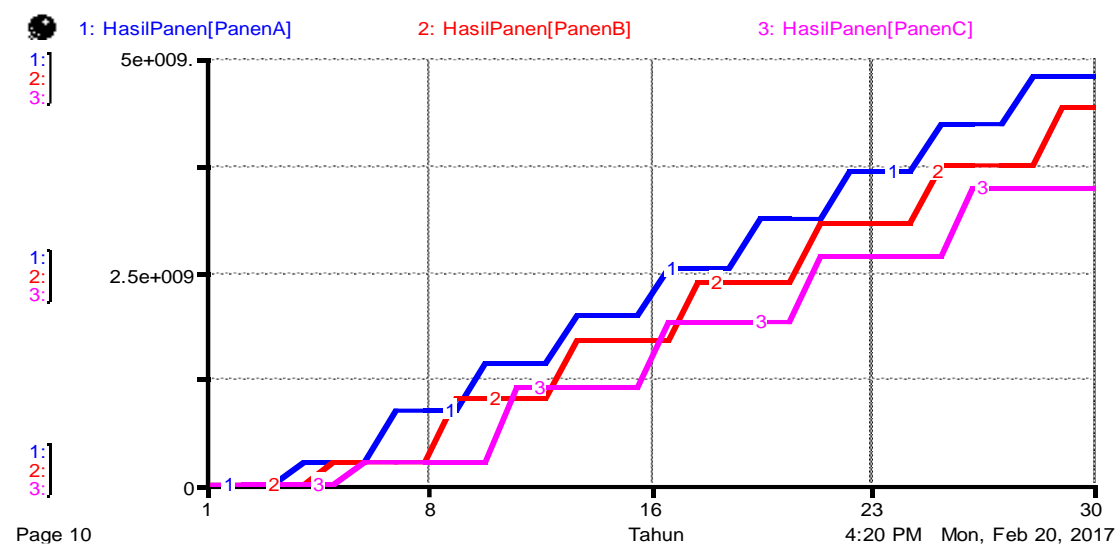

Gambar 5. Tren pemanenan batang kaliandra

Jumlah batang yang dipanen kemudian dijual dalam bentuk biomasa. Biomasa hasil pangkas dipengaruhi oleh ukuran diameter dan panjang trubusan. Abdulah et al. (2015)

8 Biomassapangkas: 1 -

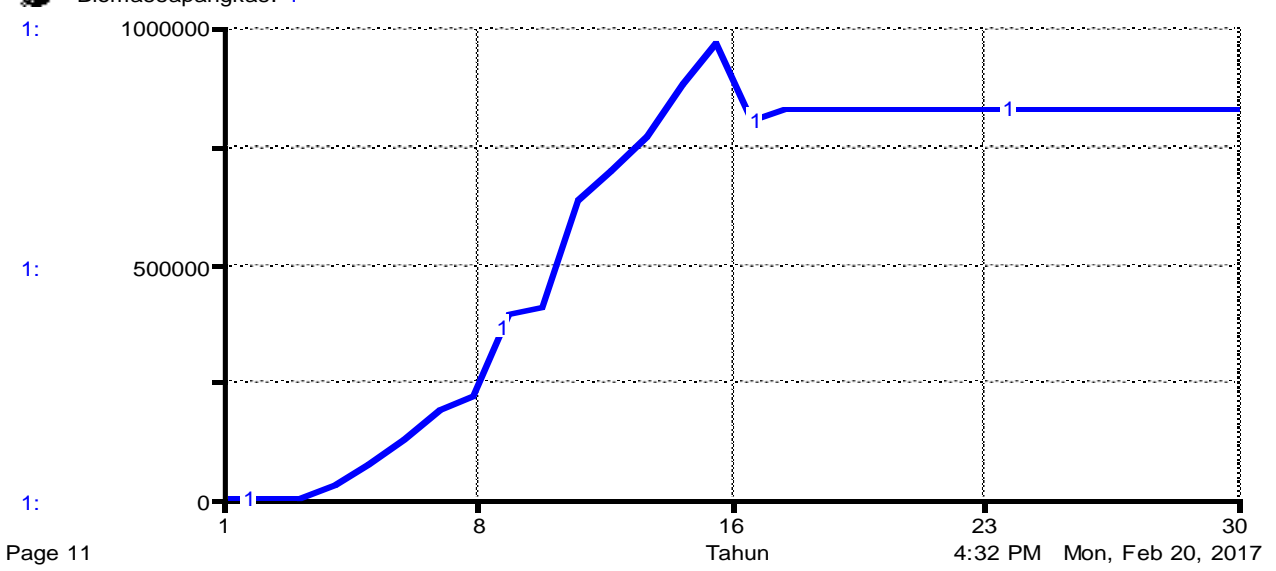

1000* 0.7. jadi 1 ton kaliandra sama dengan $700 \mathrm{~m}^{3}$. Dari hasil simulasi di tahun kedua menghasilkan 266.666,7 ton, dengan jumlah panen dihasil daur 245.571.639 ton (Gambar $6)$.

Gambar 6. Tren pertumbuhan biomasa pangkas

menyebutkan bahwa diameter hasil pangkas berkisar antara $1 \mathrm{~mm}-20 \mathrm{~mm}$ dengan nilai kalor antara $3100 \mathrm{kkal} / \mathrm{kg}$ sampai dengan $3200 \mathrm{kkal} / \mathrm{kg}$. Nilai ini tidak berbeda jauh
Gambar 6 menunjukkan bahwa biomasa pangkas akan terus naik mengikuti umur rumpun. Hal ini karena semakin tua umur rumpun maka pertumbuhan batang 
akan semakin banyak namun akan stagnan di umur 17 tahun. Pertambahan biomasa terbaik tercapai umur 8 tahun setelah penanaman mencapai 15 ton/ha dan kemudian akan terus naik 60 ton/ha di akhir waktu pengusahaan. Fenomena ini terjadi karena biomasa pangkas untuk jenis belukar seperti kaliandra sangat dipengaruhi oleh jumlah batang per rumpun. Semakin tinggi jumlah batang yang dipangkas maka biomasa akan semakin tinggi. Namun rapatnya batang dalam suatu rumpun mempengaruhi ukuran diameter batang. Sehingga berat batang berkisar antara $0,3 \mathrm{~kg}-0,5 \mathrm{~kg}$.

\section{Biaya Pembangunan HTE}

Biaya pembangunan HTE merupakan bagian dari biaya pembangunan. Biaya pembangunan tahun I Rp 16.682.666.667,dan selaras dengan PP No. P.64/MenhutII/2009 tentang standard biaya pembangunan hutan tanaman industri biaya tertinggi sebesar Rp 16.662.034.000,- Biaya pembangunan HTE merupakan bagian dari biaya pembangunan. Biaya pembangunan terdiri atas biaya penanaman dan biaya pemanenan. Biaya pemanenan bergantung pada kerapatan tegakan. Semakin rapat atau banyak batang yang dipanen maka biaya semakin tinggi Rata-rata biaya pembangunan meliputi biaya penanaman dan pemanenan mencapai Rp 33 juta/ha.

\section{Proyeksi Pendapatan HTE}

Kaliandra dipanen dengan cara dipangkas pada umur 3 tahun setelah penanaman. Untuk itu, pemanenan di tahun ke-4 sampai dengan ke-6 hanya dilakukan pada blok 1 di tahun ke-4, blok 1 dan 2 di tahun ke-5 dan blok 1,2 dan 3 di tahun ke-6 dan seterusnya. Semakin banyak rumpun yang harus dipangkas maka biaya pemanenan akan semakin tinggi. Hal ini tentunya akan menambah kumulatif biaya pembangunan HTE. Jika harga biomasa pangkas tidak sebesar biaya pembangunan

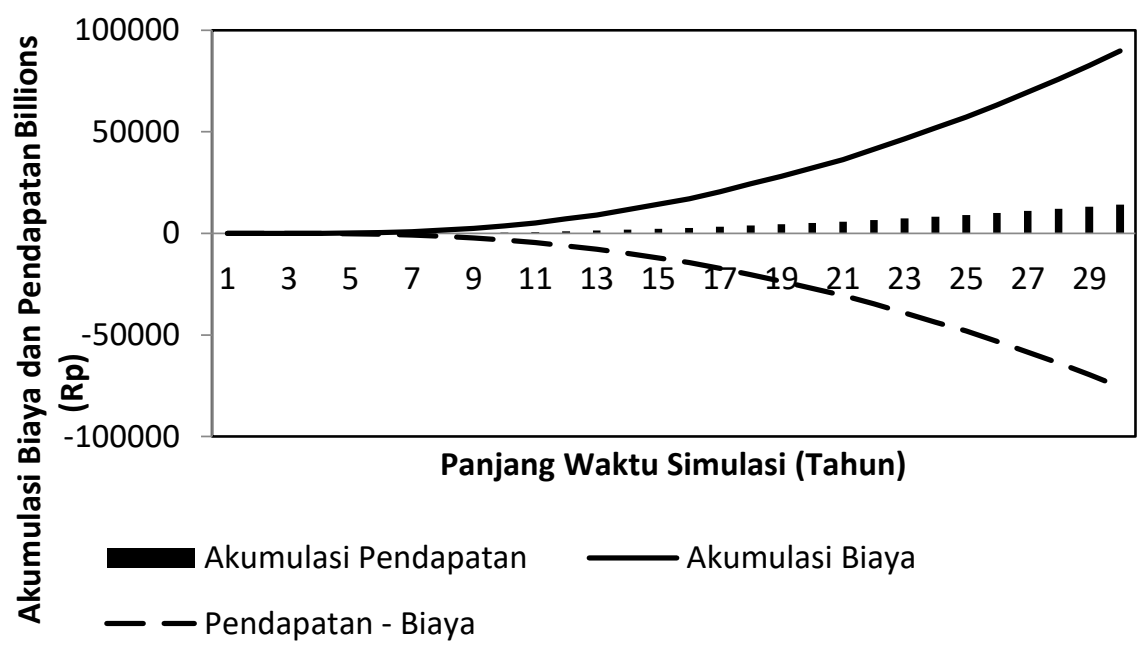

Gambar 7 Proyeksi Pendapatan HTE hasil simulasi tanpa skenario 
maka selisih antara pendapat dan biaya akan semakin besar ke arah negatif. Pada proyeksi tanpa skenario dengan harga bahan baku Rp 200.000/ton (Gambar 7).

Gambar 7 menunjukkan konsekuensi yang akan diterima oleh pemegang ijin HTI bila kondisi harga yang terbentuk tidak mempertimbangkan biaya pembangunan. pendapatan dan biaya merupakan variabel kontinyu dari tahun sebelumnya dibagi 1 ditambah suku bunga dipangkatkan tahun. Hasil simulasi menunjukkan bahwa dengan harga jual biomasa ( $\mathrm{Rp} /$ ton) sebesar $\mathrm{Rp}$ 200.000 tidak akan menjamin kelestarian usaha penyediaan bahan baku biomasa untuk penyediaan listrik (Gambar 8).

Untuk itu, agar menjamin kelestarian usaha

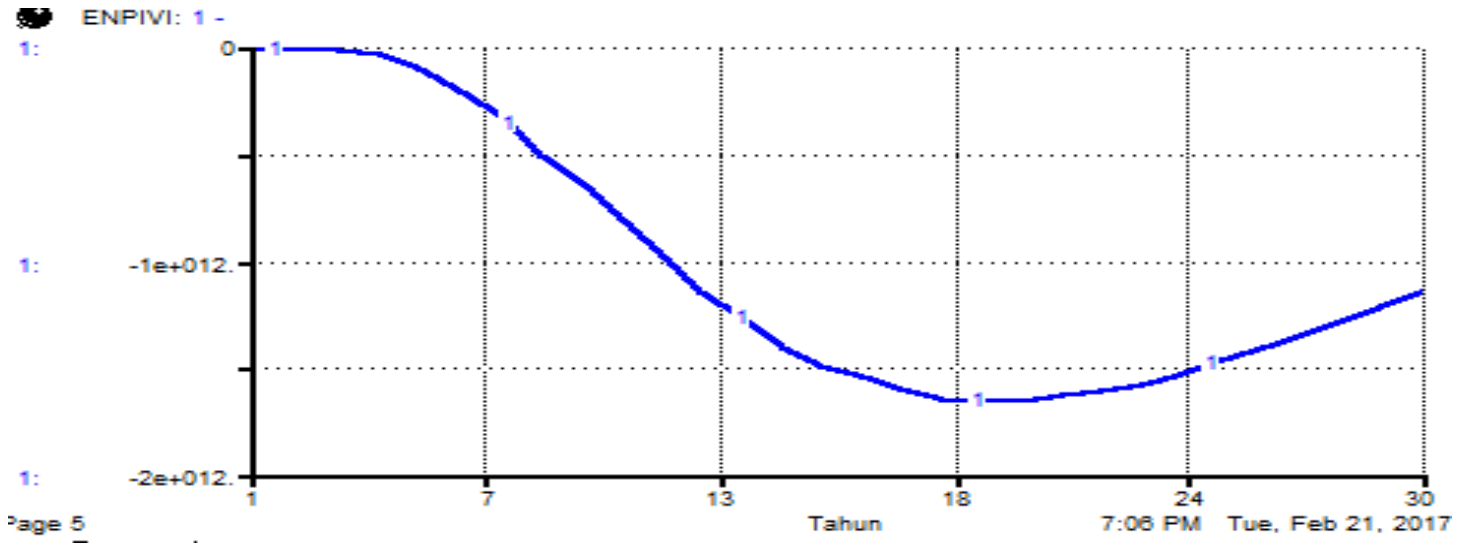

Gambar 8. Tren NPV hasil simulasi

HTI maka perlu kebijakan pemerintah sehingga selisih antara pendapatan dan biaya menjadi positif.

\section{Analisis Kelayakan Usaha}

Analisis finansial digunakan untuk mengevaluasi pendapatan maupun biaya dari sisi investor pada suatu suku bunga pinjaman tertentu (Gray et al 1985). Suku bunga yang digunakan adalah $15 \%$ biaya awal pembangunan HTE.

Analisis kelayakan yang digunakan adalah memproyeksikan niai uang yang dikeluarkan di tahun pertama terhadap nilai yang akan diterima ketika pemanenan telah dilakukan setiap tahunnya. Variabel
Gambar 8 menunjukkan bahwa tren nilai uang yang diinvestasikan dalam pembangunan HTE selalu negatif sepanjang umur pengusahaan. Meski terlihat terdapat tren menguat tidak berarti bahwa dengan memanjangkan waktu simulasi maka NPV akan positive sehingga usaha HTE dikatakan layak. Hal ini karena pada tahun ke 30 akan dilakukan permudaan sehingga biaya investasi akan meningkat.

\section{EVALUASI MODEL}

Model yang dibuat perlu dievaluasi untuk mengetahui kesesuaiannya dengan dunia nyata. Terdapat tiga tahapan evaluasi 
model yaitu mengevaluasi kelogisan model, kesesuaiannya dengan konsep model, dan perbandingan dengan data aktual (Purnomo 2012). Untuk mengevaluasi sebuah model disarankan untuk memakai kriteria kelogisan, perbandingan perilaku model dengan pola yang diharapkan dan perbandingan perilaku model dengan sistem nyata. Tahap pertama dan kedua evaluasi mengambil contoh sub model pertumbuhan kaliandra di Majalengka (Abdulah et al. 2015)dan Bali (Narendra 2014) (Gambar 9).

Gambar 9 menunjukkan terdapat kesamaan arah pertumbuhan tinggi dari hasil model simulasi dengan penelitian yang dilakukan Narendra (2014). Pada kondisi ini maka kesamaan tren dapat digunakan untuk menilai bahwa secara umum model yang dibangun dapat disebut valid.

\section{PENGGUNAAN MODEL}

Penggunaan model berfungsi untuk menerapkan model dalam skenario-skenario yang telah ditetapkan dalam rangka memberikan jawaban mengenai tujuan penelitian (Purnomo 2012). Tujuan utama yang ingin dicapai adalah menyajikan skenario atau pilihan strategi prioritas agar HTE dapat berjalan secara berkelanjutan dan menjamin kontinuitas ketersediaan bahan baku untuk listrik. Analisis yang digunakan dengan intensitas panen 50 persen, 70 persen dan 100 persen serta pembatasan harga bahan baku Rp 200.000.-, Rp 300.000.- dan Rp 400.000.-

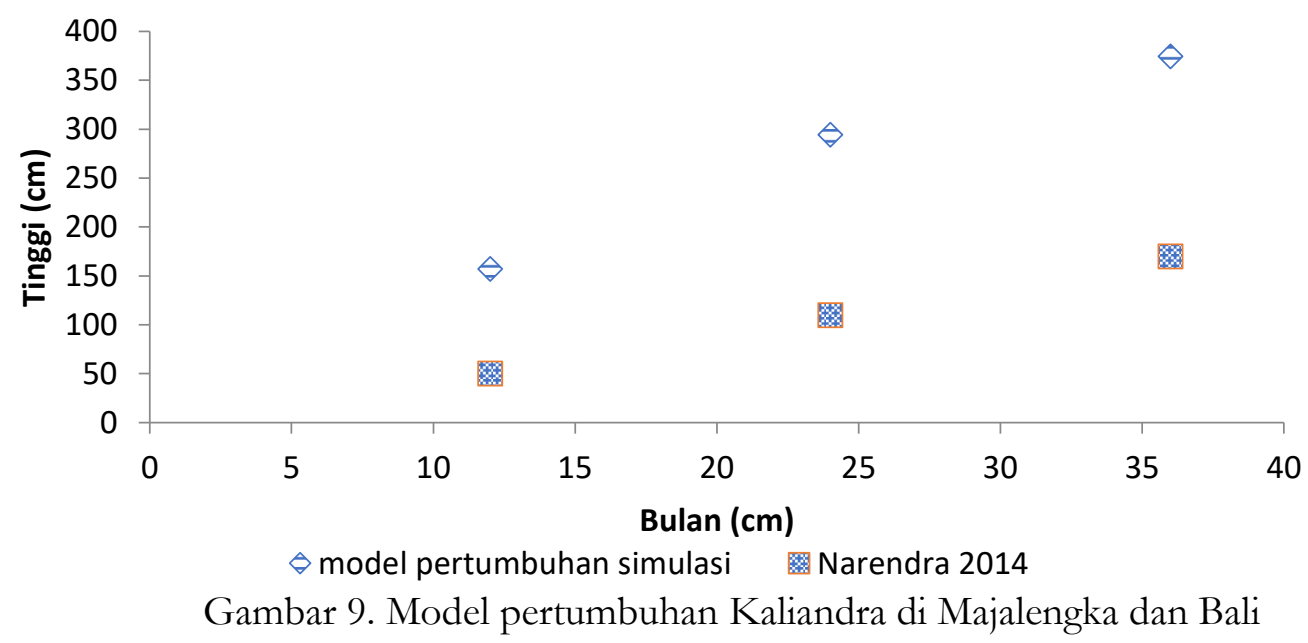


Tabel 3. Skenario Pengelolaan Kebijakan Pembangunan HTE

\begin{tabular}{|c|c|c|c|c|c|c|c|c|c|c|}
\hline \multirow{2}{*}{ Skenario } & \multicolumn{4}{|c|}{ Pilihan } & \multicolumn{3}{|c|}{$\begin{array}{l}\text { Intensitas } \\
\text { Panen }(\%)\end{array}$} & \multicolumn{3}{|c|}{ Harga (Ribu Rupiah) } \\
\hline & Pajak & Iuran & Amdal & $\begin{array}{c}\text { Stabilitas } \\
\text { Harga }\end{array}$ & 50 & 70 & 100 & 200 & 300 & 400 \\
\hline 1 & $\mathrm{v}$ & $\mathrm{v}$ & $\mathrm{v}$ & & & & $\mathrm{v}$ & & & $\mathrm{v}$ \\
\hline 2 & & & & $\mathrm{v}$ & & $\mathrm{v}$ & & & $\mathrm{v}$ & \\
\hline 3 & $\mathrm{v}$ & $\mathrm{v}$ & $\mathrm{v}$ & $\mathrm{v}$ & & $\mathrm{V}$ & & & $\mathrm{v}$ & \\
\hline 4 & $\mathrm{v}$ & $\mathrm{v}$ & $\mathrm{v}$ & & $\mathrm{V}$ & & & $\mathrm{v}$ & & \\
\hline 5 & & & & $\mathrm{v}$ & $\mathrm{V}$ & & & $\mathrm{v}$ & & \\
\hline 6 & $\mathrm{v}$ & $\mathrm{v}$ & $\mathrm{v}$ & $\mathrm{v}$ & & $\mathrm{v}$ & & & $\mathrm{v}$ & \\
\hline 7 & & & & $\mathrm{v}$ & & $\mathrm{V}$ & & & & $\mathrm{v}$ \\
\hline
\end{tabular}

\section{Skenario 1}

Skenario ini diterapkan dengan dibuat kebijakan pembebasan pajak dan pembebasan Provisi Sumber Daya hutan dan Iuran Hasil Hutan (PSDHIHH), pembebasan iuran Amdal dengan intensitas panen 100\% dan harga bahan baku ditetapkan Rp 400.000/ton apakah bisa membuat NPV positif sehingga bisa menguntungkan Dari hasil simulasi ini dapat dilihat bahwa pengembangan HTE belum layak karena nilai NPV sampai tahun ke 30 masih di negatif

\section{Skenario 2}

Skenario ini diterapkan dengan dibuat kebijakan stabilitas harga dengan intensitas panen 70 persen dan harga bahan baku ditetapkan Rp 300.000/ton apakah bisa membuat NPV positif sehingga bisa menguntungkan Dari hasil simulasi ini dapat dilihat bahwa pengembangan HTE belum layak karena nilai NPV sampai tahun ke 30 masih negatif.

\section{Skenario 3}

Skenario ini diterapkan dengan dibuat kebijakan pembebasan pajak dan pembebasan PSDHIHH, pembebasan iuran Amdal, stabilitas harga dengan intensitas panen 70 persen dan harga bahan baku ditetapkan Rp 300.000/ton apakah bisa membuat NPV positif sehingga bisa menguntungkan Dari hasil simulasi ini dapat dilihat bahwa pengembangan HTE belum 
layak karena nilai NPV sampai tahun ke 30 masih negatif.

\section{Skenario 4}

Skenario ini diterapkan dengan dibuat kebijakan pembebasan pajak dan pembebasan PSDHIHH, pembebasan iuran Amdal dengan intensitas panen 50 persen dan harga bahan baku ditetapkan $\mathrm{Rp}$ 200.000/ton apakah bisa membuat NPV positif sehingga bisa menguntungkan Dari hasil simulasi ini dapat dilihat bahwa pengembangan HTE belum layak karena nilai NPV sampai tahun ke 30 masih negatif.

\section{Skenario 5}

Skenario ini diterapkan dengan dibuat kebijakan stabilitas harga dengan intensitas panen 50 persen dan harga bahan baku ditetapkan Rp 200.000/ton apakah bisa membuat NPV positif sehingga bisa menguntungkan Dari hasil simulasi ini dapat dilihat bahwa pengembangan HTE belum layak karena nilai NPV sampai tahun ke 30 masih negatif.

\section{Skenario 6}

Skenario ini diterapkan dengan dibuat kebijakan pembebasan pajak dan pembebasan PSDHIHH, pembebasan iuran Amdal, stabilitas harga dengan intensitas panen 70 persen dan harga bahan baku ditetapkan Rp 300.000/ton apakah bisa membuat NPV positif sehingga bisa menguntungkan Dari hasil simulasi ini dapat dilihat bahwa pengembangan HTE disebut layak karena nilai NPV pada tahun 5 sudah positif dan di tahun ke 7 sudah terdapat peningkatan.

\section{Skenario 7}

Skenario ini diterapkan dengan dibuat kebijakan stabilitas harga dengan intensitas panen 70 persen dan harga bahan baku ditetapkan Rp 400.000/ton apakah bisa membuat NPV positif sehingga bisa

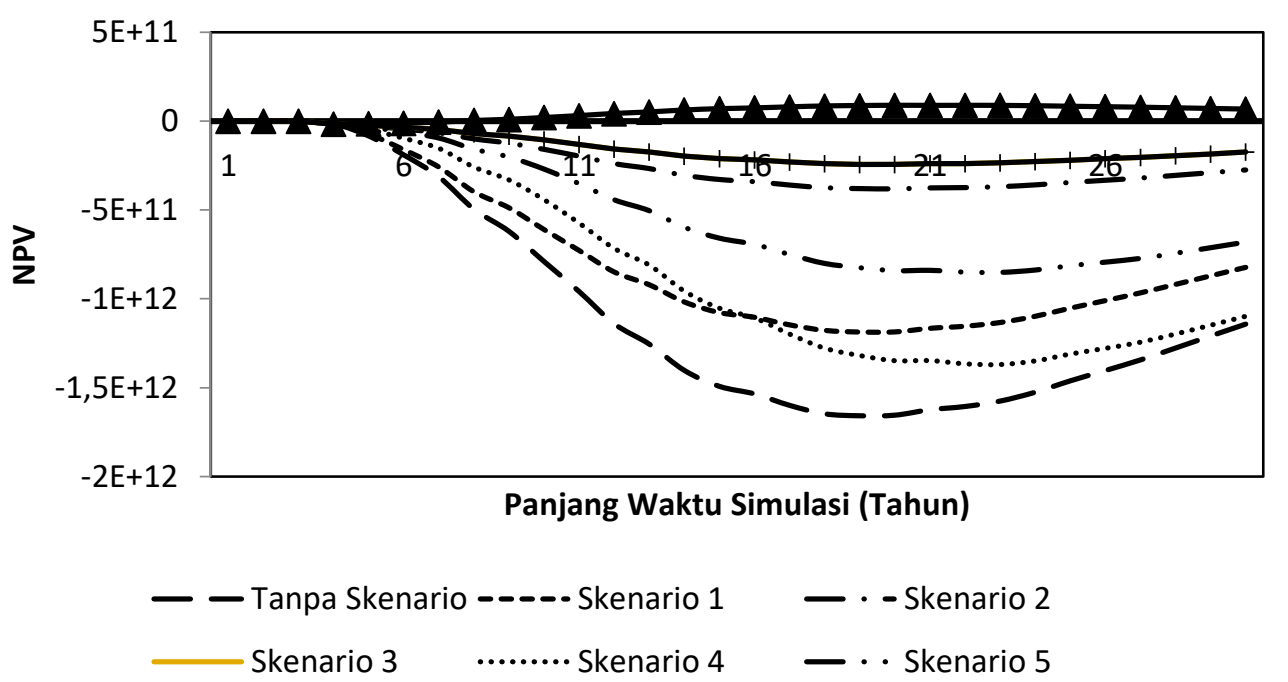

Gambar 10. Hasil skenario Pengelolaan Pembangunan HTE 
menguntungkan. Dari hasil simulasi ini dapat dilihat bahwa pengembangan HTE disebut layak karena nilai NPV pada tahun 6 sudah positif dan di tahun ke 7 sudah terdapat peningkatan.

Dari hasil simulasi skenario ke-tujuh merupakan skenario yang layak karena NPV yang dihasilkan positif, tetapi walaupun NPV positif tetap harus mempertimbangkan manajemen resiko, analisis resiko yang paling sederhana adalah analisis sensitivitas, dengan menilai unsur-unsur finansial yang berpengaruh dengan mengkaji sejauh mana perubahan unsur-unsur dalam aspek finansial kegiatan usaha yang dilaksanakan dengan melihat hasil kegiatan usaha jika terjadi perubahan-perubahan dalam dasardasar perhitungan biaya dan manfaat (Kadariah 1999). Analisis sensitivitas (kepekaan) menurut Nugroho (2008) adalah suatu teknik untuk menguji sejauh mana hasil analisis peka terhadap faktor-faktor yang berpengaruh terhadap perubahan keuntungan yang disebabkan oleh faktorfaktor yang berpegaruh. Stabilitas harga merupakan yang paling berpengaruh terhadap potensi usaha, ketika harga dibawah $\mathrm{Rp} \mathrm{380.000/ton} \mathrm{maka} \mathrm{potensi}$ usaha menjadi negatif. Sehingga stabilitas harga merupakan faktor yang berpengaruh terhadap kelayakan usaha.
Harga jual bahan baku Rp 400.000/ton mampu menghasilkan $800 \mathrm{kWh}$ lebih besar dibandingkan produksi listrik dengan BBM fosil. Sebagai contoh harga pertamax di Kabupaten Maluku Tengah sebesar Rp 11.000 /liter mampu menghasilkan 4,2 kWh. Bila dibandingkan maka harga listrik fosil mencapai Rp 2700/kWh, sementara harga listrik biomasa hanya sebesar Rp 500/kWh. Dengan kata lain terdapat efisiensi yang sangat tinggi akibat dari penggunaan biomasa. Namun, perhitungan ini belum mempertimbangkan biaya pembangkit, transportasi dan jaringan. Untuk biaya jaringan akan lebih murah jika dikembangkan pada kawasan lokal dengan pola small scale gassifier power plant.

\section{REFERENSI}

[Permen LHK]. 2015. Peraturan Menteri Lingkungan Hidup dan Kehutanan Nomor 12 tahun 2015 tentang Pembangunan Hutan Tanaman Industri.

Abdulah L. Harbagung. Yulianti M. Oktian S. Simatupang M B. 2015. Laporan Hasil Penelitian: Dinamika Pertumbuhan Kayu Energi. Bogor: Pusat Penelitian dan Pengembangan Hutan

Arifin HS, Wulandari C, Pramukanto q, Kaswanto RL. 2009. Analisis Lanskap Agroforestri: Konsep, Metode, dan Pengelolaan Agroforestri Skala Lanskap 
dengan study Kasus Indonesia, Filipina, Laos, Thailand, dan Vietnam. IPB Press.

Bogor, Indonesia

Bappenas dan Cifor. 2016. Tantangan dan

Peluang Pengembangan Bioenergi di Indonesia. Bogor: Cifor.org.

Bildirici M. and Özaksoy F. 2016. Woody

Biomass Energy Consumption and

Economic Growth in Sub-Saharan

Africa. Journal Procedia Economics and

Finance 38. $287-293$

[BIN] Badan Intelijen Negara. 2014.

Ketahanan Energi Indonesia 2015 - 2025

Tantangan dan Harapan. Jakarta: CV.

Rumah Buku.

[BPPT] Badan Pengkajian Penerapan

Teknologi. 2016. Outlook Energi

Indonesia 2016. Jakarta: BPPT 2016

Chamberline J R. 2000. Improving seed production in Caliandra calothyrsus: A field manual for researchers and extension workers. Oxford: Oxford Forestry Institute, University of Oxford.

Djatmiko B. 2012. Studi Kelayakan Bisnis. Bandung (ID): STEMBI-Bandung Business School.

Firdaus M, Harmini, Afendi F M. 2011. Aplikasi Metode Kuantitatif untuk. Manajemen dan Bisnis. Bogor (ID). IPB Press
Grant J W. E K Pedersen and S L Marin. 1997. Ecology and Natural Resource Management: System Analysis and Simulation. Reading, Massachusetts.

Gray C. L Karlina. Kadariah. 1985. Pengantar Evaluasi Proyek. Edisi Pertama. Jakarta: PT Gramedia

Hendrati, Rina Laksmi, and Nur Hidayati. 2014. Budidaya Kaliandra (Calliandra Calothyrsus) Untuk Bahan Baku Sumber Energi.

IRENA. 2015. Renewable Power Generation Costs In 2014. International Renewable Energi Agency.

Jurgensen C. Kollert W. Lebedys A. 2014. Assessment of Industrial Roundwood Production. Rome: FAO.

Juwito A F. Pramonohasi S. Haryono T. 2012. Optimalisasi Energi Terbarukan pada Pembangkit Tenaga Listrik dalam Menghadapi Desa Mandiri Energi di Margajaya. Jurnal Ilmiah Semesta Teknika Vol. 15, No. 1, 22-34.

Kadariah. 1999. Evaluasi Proyek: Analisa Ekonomis. Jakarta (ID): Universitas Indonesia.

Kholik I. 2015. Pemanfaatan Energi Alternatif SebagaI Energi Terbarukan Untuk Mendukung Subtitusi Bbm. Jurnal IPTEK Vol.19 No. 2. 
Narendra B H. 2014. Pengaruh Perbaikan Kondisi Tanah Terhadap Pertumbuhan Kaliandra (Calliandra calothyrsus) Dan Buni (Antidesma bunius) Di Kawasan Konservasi Gunung Batur, Bali. Jurnal Penelitian Hutan dan Konservasi Alam, 101-111.

Nizam M. 2008. Pembangkit Listrik Terdistribusi (Distributed Generation) Sebagai Upaya Pemenuhan Kebutuhan Energi Listrik Di Indonesia. Jurnal UNS kanika, Vol 7 Nomor 1

Nugroho J. Setiadi, SE., MM. 2008. Perilaku Konsumen :Konsep dan Impilikasi Untuke Strategi dan Penelitian Pemasaran. Jakarta : Kencana

Pamoengkas P dan Aasycarya D. 2015. Keunggulan Kaliandra Merah. http:// http://greenmadura.com/

Purnomo H. 2003. Model Dinamika Sistem untuk pengembangan alternatif kebijakan pengelolaan hutan yang adil dan lestari. J Man Hut Trop., $9(2): 45-62$

Purnomo H. 2004. Memfasilitasi Pengelolaan Hutan Kolaboratif Menggunakan Pemodelan Dinamika Sistem. J Man Hut Trop, 10(2):32-46.
Purnomo H. 2012. Pemodelan dan simulasi untuke pengelolaan adaptif sumber daya alam dan lingkungan. Bogor (ID): IPB Press.

Sadapotto A, Kartodihardjo H, Triwidodo H, Darusman D, Sila M. 2010. Penataan Institusi untuk peningkatan kinerja persuteraan alam di Sulawesi Selatan. Jurnal Forum Pascasarjana. 33(2): 133-140.

Stassen H E. 1995. Small-Scale Biomass Gasifiers for Heat and Power. World Bank Technical Paper Number 296.

Sudarmalik. 2014. Ekonomi Politik Pembangunan Hutan Tanaman Industri (disertasi). Bogor: Program Pascasarjana, Institut Pertanian Bogor. Triatmojo F. 2013. Dinamika Kebijakan Diversifikasi di Indonesia: Analisis Kebijakan Pengembangan Energi Terbarukan di Indonesia. Jurnal Ilmiah Administrasi Publik dan Pembangunan, vol. 4 No. 2 Juli - Desember 2013. 